\title{
Ulema on Kompas News: A Corpus-Based Critical Discourse Analysis
}

\author{
Siti Sarah Sofyaningrat ${ }^{1}$, Untung Yuwono ${ }^{2}$, Totok Suhardiyanto ${ }^{3}$ \\ \{1 sitisarahs.11c@gmail.com, ${ }^{2}$ untungy@gmail.com, ${ }^{3}$ suhardiyanto@gmail.com\} \\ Linguistics Studies Program, Faculty of Humanities, Universitas Indonesia
}

\begin{abstract}
This study aims to describe how topics about ulemas are represented in Kompas. To this end, a corpus-based critical discourse analysis is performed by employing a keyword method. The corpus is built from ulemas-related news collected from KOMPAS from January 2017 to April 2019. After the news corpus is analyzed, the keywords found are then categorized into semantic categories to find out the semantic preference of ulemas-related news. A concordance is then generated for each of such keywords in order to obtain the context of the news and further to find out the main topic discussed. As the result, several salient topics are found in ulemas-related news, namely (1) politics, (2) group, (3) blasphemy, and (4) education.
\end{abstract}

Keywords: Ulema, Linguistics Corpus, Critical Discourse Analysis, Online media, Newspaper

\section{Introduction}

The end of 2016 has marked high dynamics in Indonesian politics. During this time, ulemas started to drew attentions after claiming that Ahok's statement in one of his speeches in 2016 was a blasphemy against Qur'an. Even after 2016, news about ulemas still continued, from the ones related to Ahok, the criminalization of ulemas, and the influence of ulemas in Indonesian politics approaching the presidential election in April 2019.

The word ulama "ulema" has been well-known in Indonesia since a long time ago. Its variation in different regions such as kiai, ajengan, tengku, buya, and other traditional titles adds to its prominence in Indonesia. As the time goes, the role of ulemas have become more important. Ulemas continue to assume roles in many aspects in the society, from religion, social, and politic [1][9][17]. These increasingly-important roles have made ulemas gain wide attention from the media, especially after the recent series of events they were involved in.

Kompas is regarded as one of Indonesian media that consistently reports news about ulemas on both of their printed daily newspaper and their online platform (Kompas.com). As a media, Kompas is one of the largest medias in Indonesia and, recordedly, is the most-read media with various platforms online. Media can provide a clear portrayal of how ulemas, which are becoming an interesting topic nowadays, are positioned to influence the society. As Baker, et al. points out, many studies have shown newspapers' capability to change public opinion [4]. Here, a media representation refers to how a certain group is portrayed on the media with information and facts that are selected and delivered in a certain way [6]. Baker 
integrates corpus linguistic approach and critical discourse analysis into a corpus-assisted discourse analysis, that is expected to minimize the researcher's bias in conducting their study [3]. A corpus is a large collection of texts. Corpus linguistics can portray the real use of language [10][13][16]. Moreover, the availability of various related software has made it possible to process large linguistic data and solve complicated calculations in no time accurately. Processing information like appearance frequency and running relevant statistical tests make it possible to present the data in various ways and make it easier to observe linguistic patterns in a corpus or linguistic data set [4].

Despite many studies that have been conducted on Kompas newspaper, both the printed and online versions, up to now none explores how ulemas are positioned in Kompas. However, some studies related to the Islam-defense action and the framing of news about Basuki Tjahaja Purnama's (Ahok's) blasphemy against Islam show that Kompas was in favor of Ahok, as seen in how it tried to argue that Ahok is not guilty of the alleged blasphemy and showed the political aspect behind the religion-related issue [14]. On the above account, this study attempts to reveal topics related to ulemas as represented by Kompas online. To this end, a keyword analysis is performed by employing a corpus linguistic approach

\section{Research Method}

This study employs a corpus-based discourse analysis approach. In other words, it is a mixed-method study. A mixed method is employed when either separate method fails to satisfactorily answer the research questions proposed and to strengthen one another [11]. The corpus used in this study consists of news articles collected from two Kompas online news platforms, namely Kompas.com and Kompas.id, since January 2017 to April 2019. These data were purposively selected as they are considered to represent phenomena related to ulemas that are reported within such a period. There are a total of 2,228 news articles from the period, with a total of 755,022 tokens. A keyword analysis was performed to see which topics are prominent in the ulemas-related news besides the word ulama "ulema" itself. The keywords resulting from the comparison between KBU and IndonesianWac were then classified using the USAS (UCREL Semantic Analysis System) [2], after which their semantic preferences were determined based on their concordances for further analysis.

\section{Results And Discussion}

A keyword analysis reveals the uniqueness of a focus corpus, which reflects prominent topics of discussion in such a corpus. Table 1 lists the 15 highest keywords in KBU based on the total of 100 keywords in KBU.

Table 1 Keywords with the Highest Keyness Score

\begin{tabular}{lll}
\hline Word & Keyness & Frequency \\
\hline Jokowi & $4,046,690$ & 4,293 \\
Maruf Amin & $3,555,960$ & 3,371 \\
ketum "chairman" & 801,080 & 1,315 \\
Ahok & 705,320 & 674 \\
hoaks "hoax" & 574,690 & 546 \\
\hline
\end{tabular}




\begin{tabular}{lll}
\hline Word & Keyness & Frequency \\
\hline Sandiaga & 543,440 & 604 \\
Rizieq Shihab & 523,010 & 495 \\
Said Aqil Siroj & 362,720 & 343 \\
GNPF & 312,100 & 295 \\
Imin & 232,850 & 329 \\
Prabowo & 211,720 & 2,034 \\
$\begin{array}{l}\text { Rais aam } \\
\text { "supreme leader" }\end{array}$ & 191,880 & 181 \\
$\begin{array}{l}\text { Maimoen Zubair } \\
\text { cawapres }\end{array}$ & 172,900 & 163 \\
"vice presidential & 171,460 & 1,080 \\
candidate" & & \\
Sohibul Iman & 159,190 & 150 \\
\hline
\end{tabular}

As keyword analysis shows the content of a corpus and the topic discussed, the above table shows that the two highest topics of ulemas-related news published by Kompas are related to the names of political figures, namely Jokowi and Maruf Amin.

Baker states that a keyness analysis should consider words that have the same semantic meaning or grammatical function [3]. Consequently, it is necessary to categorize keywords for a comprehensive discourse analysis.

Following that logic, all KBU keywords as appearing on Sketch English are categorized based on the context of the complete news, as seen from their concordance. Then, the keywords are categorized semantically based on the USAS (UCREL Semantic Analysis System) [2]

From the category, category $\mathrm{Z}$ that contains names and grammatical items is ranked highest in the list of keywords. In fact, the top 15 keywords are dominated by names of person and institution; only three keywords are names of regional, and only one is a lexical word (hoaks "hoax").

Based on the semantic categorization, the semantic preferences of such keywords can be determined, for further determining the topics of reporting. In this study, semantics preferences are determined by analyzing the categorized keywords while taking account of their contexts. The following are the semantic preferences of the semantically-categorized keywords along with the topics.

Table 3. Semantic Preferences and Topics of KBU Keywords

\begin{tabular}{|c|c|c|}
\hline Category & Preferences & Topics \\
\hline Z Names and grammar & $\begin{array}{l}\text { Names of political and governmental figures, names of } \\
\text { locations, names of ulemas, names of organizations, and } \\
\text { names related to legal cases. }\end{array}$ & $\begin{array}{l}\text { Politics } \\
\text { Groups }\end{array}$ \\
\hline $\begin{array}{l}\text { S Social actions, states, } \\
\text { and processes }\end{array}$ & Organizations affiliated with ulemas & \\
\hline $\begin{array}{l}\text { G Government and } \\
\text { public }\end{array}$ & Political parties, presidential election, blasphemy case & \\
\hline P Education & Islamic education & Blasphemy \\
\hline $\begin{array}{l}\text { X Psychological actions, } \\
\text { states, and processes }\end{array}$ & Presidential election & \\
\hline $\begin{array}{l}\text { A General and abstract } \\
\text { Terms }\end{array}$ & Characteristics/Traits & Education \\
\hline $\mathrm{N} \quad$ Numbers & Presidential election & \\
\hline
\end{tabular}




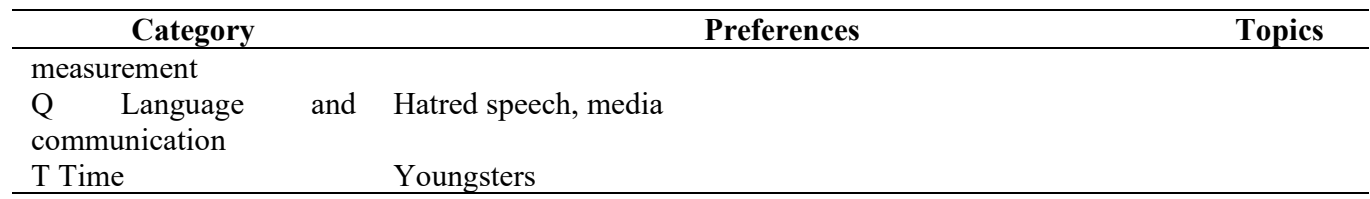

\subsection{Politics}

Politics appears as a prominent news topic in the corpus, showing that it is widely reported by Kompas through ulemas-related news. This is seen from how the names of political figures dominate the keywords in the corpus and how political contexts still underlie the keywords even across the categories.

Table 4. Concordance of Names of Political Figures

\begin{tabular}{|c|c|c|c|}
\hline & $\begin{array}{l}\text { Jokowi tidak anti-ulama. Buktinya, sebut } \\
\text { dia, }\end{array}$ & Jokowi & $\begin{array}{l}\text { menggandeng dirinya sebagai } \\
\text { cawapres. }\end{array}$ \\
\hline & Forum ijtima ulama merekomendasikan & Prabowo & $\begin{array}{l}\text { sebagai Calon Presiden RI pada } \\
\text { Pilpres }\end{array}$ \\
\hline & Bertemu ulama Jember, & & $\begin{array}{l}\text { Minta Doa dan Nasihat. Calon } \\
\text { Presiden }\end{array}$ \\
\hline & Salah satu ulama pendukung Cagub & Khofifah & $\begin{array}{l}\text { Indar parawansah, } \\
\text { Syafaat, }\end{array}$ \\
\hline
\end{tabular}

From the above concordance, it is seen that an ulema is considered as someone that gives blessings, recommendations, advices, and supports to political figures. Besides, an ulema was involved in a political contestation because Jokowi asked him to be his running mate in the presidential election to prove that Jokowi was not anti-ulema as alleged.

Political figures approach ulemas by paying them a visit or, in Indonesian term, silaturahim. Evidently, the word bersilaturahim "to pay a visit" appear prominently as a verb among nouns.

Table 5. Concordance of the Word Bersilaturahim

\begin{tabular}{llll}
\hline $\mathbf{1}$ & Selain sowan ke sejumlah Kiai untuk & bersilaturahim & $\begin{array}{l}\text { Gus } \\
\text { menyempatkan berziarah }\end{array}$ \\
$\mathbf{2}$ & Diketahui, pekan lalu Prabowo sempat & bersilaturahim & dengan beberapa Ulama Pimpinan \\
$\mathbf{3}$ & $\begin{array}{l}\text { Di sela agenda kampanye, Sandiaga } \\
\text { menyempatkan, }\end{array}$ & bersilaturahim & dengan Tokoh masyarakat dan Ulama \\
& $\begin{array}{l}\text { hari pertama kampanye terbuka itupun } \\
\text { Jokowi }\end{array}$ & bersilaturahim & dengan Para Ulama Banten, \\
\hline
\end{tabular}

From the above concordance, it can be seen that the word bersilaturahim is closely related to politicians and campaign. Although a silaturahim agendum is not always carried out during or in between a campaign, the word itself still appears strongly in campaign-related news.

Granted, the period from 2017 to 2019 was marked by series of political elections including presidential election, legislative election, and regional head elections, so unsurprisingly the ulemas-related news during such a period would revolve around political themes. 
In these political themes, Kompas has portrayed ulemas as being closely related to politics, either as politician themselves or supporters of other political figures.

\subsection{Groups}

In category S (Social actions, states, and processes), the keywords form a semantic preference of organizations that affiliated with ulemas, with subcategories of groups and affiliations. This shows that ulemas are portrayed as being affiliated with a certain organization or institution. The keywords included in this preference are ketum "chairman", Rais Aam "supreme leader", Nahdliyin "people affiliated with Nahdlatul Ulama", PBNU "Nahdlatul Ulama Central Board", $P W N U$ "Nahdlatul Ulama Regional Board" (positions and functions in organizations), $N U$ "Nahdlatul Ulama", $M U I$ "Indonesian Ulema Council", $G N P F$ "National Movement to Safeguard Fatwas", and ormas "societal organization" (Islamic organizations).

Table 6. Concordance of the Word Ormas

\begin{tabular}{|c|c|c|c|c|}
\hline 1 & $\begin{array}{l}\text { memandang umat Islam } \\
\text { diwakili }\end{array}$ & yang & ormas & $\begin{array}{l}\text { Islam sebagai kekuatan } \\
\text { membangun Indonesia. }\end{array}$ \\
\hline 2 & Dia juga mengingatkan bahwa & & ormas & Islam Menjadi bagian dari proses berkebangsaan \\
\hline 3 & $\begin{array}{l}\text { Nazri pun mengimbau } \\
\text { Tokoh-Tokoh }\end{array}$ & kepada & ormas & agar menyosialisasikan Hal tersebut \\
\hline 4 & $\begin{array}{l}\text { para Ulama, } \\
\text { pemimpin }\end{array}$ & agama, & ormas & $\begin{array}{l}\text { dari Pondok Pesantren ikut bersama selesaikan } \\
\text { masalah ini }\end{array}$ \\
\hline
\end{tabular}

Table 4.9 above shows that societal organizations are portrayed positively by Kompas online. In other words, Islamic societal organizations are seen as a strategic power that takes part in the process of developing the nation and help addressing problems.

\subsection{Blasphemy}

Aside from political themes, ulemas are also reported in legal domain, among which is a blasphemy case.

Table 7. Concordance of the Word Penodaan

\begin{tabular}{llll}
\hline $\mathbf{1}$ & Ahok membantah soal tuduhan & Penodaan & $\begin{array}{l}\text { agama di Balai Kota, acara Partai } \\
\text { Nasdem, } \\
\text { agama karena mengutip surat Al- } \\
\text { Maidah }\end{array}$ \\
$\mathbf{3}$ Adapun Ahok didakwa melakukan & $\begin{array}{l}\text { Maruf Amin menjadi saksi dalam sidang kasus } \\
\text { dugaan }\end{array}$ & $\begin{array}{l}\text { Penodaan } \\
\text { agama oleh Ahok pada hari ini. }\end{array}$ \\
4 & Penodaan & $\begin{array}{l}\text { agama dan Ulama, yaitu Komisi } \\
\text { Fatwa, }\end{array}$ \\
\hline
\end{tabular}

The phrase penodaan agama "blasphemy" appears together with the word tuduhan "accusation", dugaan "allegation', and didakwa "to be charged/accused", dominating the entire concordance with a total of 171 context lines. This indicates that Kompas online sees this case of blasphemy against Islam and ulemas as merely an accusation and allegation made by those who were on the opposite side of Ahok. This case of blasphemy against Islam and ulemas further triggered and action called Aksi Bela Islam 212 "the 212 action to defense Islam" by the end of 2016, based on the related MUI fatwa. 
From the analysis, it is seen that Kompas online was building a discourse that the blasphemy case that involved ulemas was merely an accusation and allegation, leading to the issue of abolishing the blasphemy law.

\subsection{Education}

Two keywords appear in the education topic, namely ponpes "Islamic boarding school"and santri "a student of Islamic boarding school". Ponpes, an acronym for pondok pesantren. Pondok refers to a building that serves as a dormitory where students and teachers live, and pesantren refers to a traditional Islamic educational institution equipped with learning, praying, and boarding facilities [5][12]. In relation with ulemas, pondok pesantren is a school that produces ulemas[14], and santri is a student that learns to become an ulema.

In Kompas online news articles, themes concerning the word ponpes and santri are dominated by visits made by political and governmental figures, and only a few of them are related to education. The following are some contexts in which the word ponpes is not related to political visit, but education.

Table 8. Concordance of the Word Ponpes

\begin{tabular}{llll}
\hline $\mathbf{1}$ & mendapat pengaruh radikal dari luar & ponpes & "Ajaran dan suasana Pondok tidak mendukung \\
$\mathbf{2}$ & Jadi Pelaku Penyerangan Gereja, & Ponpes & Payaman Perketat Seleksi Pengasuh Pondok. \\
$\mathbf{3}$ & sama dengan kurikulum yang dipakai di & ponpes & umumnya. Kami belajar menghafal Alquran \\
$\mathbf{4}$ & Islam Rahmatan Lil Alamin & ponpes & tidak pernah ajarkan kekerasan. \\
\hline
\end{tabular}

In the above context lines, the word ponpes is accompanied by the words pendidikan "education", ajaran "teaching", kurikulum "curriculum", ajarkan "to teach", lingkungan di dalam ponpes "environment inside ponpes". However, all those words appear in news related to themes like radicalism, church attack, and violence. Even in the 3rd line that seem like it is not related to radicalism or church attack, such themes still wrap the original news articles from which themes contexts are taken [18].

In addition to ponpes, santri is also found as a keyword. Santri is portrayed as a target that receive education, as seen in some phrases like program mengintelekkan "program to educate", memperoleh berbagai pendidikan "receive various educations", menyasar peningkatan keterampilan para santri "aims to improve the students' skills". Additionally, santri is also described as a student that possess profound knowledge about religion and is active in entrepreneurship, as evident from the word santripreneur.

\section{Conclusion}

This study is a corpus-based critical discourse analysis that aims to reveal how ulemas are represented or portrayed in news articles in two Kompas online platforms, namely kompas.com and kompas.id. To that end, a corpus linguistic approach, specifically keyword method and concordance analysis, is employed to process the data before a critical discourse analysis is performed for exploration and interpretation outside the text.

Keyword analysis on the corpus data reveals that there are four prominent topics in Kompas online, namely (1) politics, (2) groups, (3) blasphemy, and (4) education. Politics comes as the first prominent topic in the corpus, as evident from how Kompas in many of its 
news reporting portrays ulemas as figures that are closely related to politics. This can be seen from the appearance of names of political figures, ulemas associated with politics, and ulema groups affiliated with political issues that dominate the keywords.

The revealed topics are highlighted by Kompas online when reporting news about ulemas. The resulting keywords are dominated by politics-related words with a significant frequency of appearances, indicating that politics become the main topic that wraps ulemas-related news on Kompas online.

\section{References}

[1] As'ad, M. 2010. Religion and Politics in Indonesia: Attitudes and Influences of the Indonesian Council of ULAMA (MUI) of the General Elections. Leiden University.

[2] Archer, D., Wilson, A., \& Rayson, P. 2002. Introduction to the USAS category system. retrieved from: http://ucrel.lancs.ac.uk/usas/usas_guide.pdf

[3] Baker P. 2006. Using corpora in discourse analysis. London: Continuum Discourse Series.

[4] Baker, P.: Gabrielatos, C. McEnery, T. 2012. Sketching Muslims: A Corpus Driven Analysis of Representations Around the Word 'Muslim' in the British Press 1998-2009. Oxford: Oxford Universitiy Press.

[5] Dhofier, Z. 1983. Tradisi Pesantren Studi tentang Pandangan Hidup Kyai. Jakarta: LP3S.

[6] Eriyanto. 2005. Analisis Wacana Pengantar Analisis Teks Media. Yogyakarta: LKis.

[7] Fairclough, N. 1995. Media Discourse. London: Bloomsbury Academic.

[8] Fridiyanto. 2017. Kaum Intelektual dalam Catatan Kaki Kekuasaan. Lampung: GRE Publishing.

[9] Kaptein, N. J.G. 2004. Ulama: Fatwas and Religious Authority in Indonesia dalam Archives de sciences sociales des religions, 49e Année, No. 125, AuthoritésReligieuses en Islam. EHESS.

[10] Lindquist, H. 2009 Corpus Linguistics and the Description of English (Edinburgh Textbooks on the English Language-Advanced). Edinburgh: Edinburgh University Press.

[11] Litosseliti, L. 2010. (ed) Corpus Methods in Linguistics. London: Continuum.

[12] Madjid, N. 1997. Bilik-Bilik Pesantren Sebuah Potret Perjalanan. Jakarta: Paramadina.

[13] McEnery, T., and Wilson, A. (1996) Corpus linguistics: An introduction. Edinburgh: Edinburgh University Press.

[14] Muchtar, A. 2001. Arah Baru Pendidkan Islam di Indonesia. Jakarta: Logos Wacana Ilmu.

[15] Rohmadi, F. Wangi, M. S., Siswanta. 2017. Analisis Framing Pemberitaan Kasus Dugaan Penistaan Agama Basuki Tjahaja Purnama di Media Online Kompas.com dan Hidayatullah.com. Jurnal Solidaritas Vol 1, No 1.

[16] Sinclair, John McH.(2003) Reading Concordances. Pearson Longman.

[17] Van Dijk, C. 1996. Ulama And Politics. Bijdragen Tot De Taal-, Land- En Volkenkunde, 152(1), 109-143. Brill.

[18] K. Saddhono, "Language and superdiversity: Indonesians knowledging at home and abroad. By Zane Goebel." Soc. Stu. vol. 12 no.1 pp. 113-118, 2018 